\title{
Learning from Visual Materials: A Psycho-Didactic Experiment
}

\author{
Tomáš Svatoš - Martina Maněnová* \\ Received: February 16, 2017; received in revised form: March 12, 2017; \\ accepted: March 13, 2017
}

\begin{abstract}
:
Introduction: The authors consider a book (as a pedagogical text) a traditional and timeless source of knowledge for many different groups of learners. It is a known fact that textbook authors, teachers, researchers, etc. generally pay more attention to the text part of the book than to its visual materials. However, the latter are just as important in understanding the subject matter and its applications as textual information on the topic.
\end{abstract}

Methods: The psycho-didactic experiment described in this paper aims to widen the findings about the perception and understanding of visual parts of textbooks for pupils in their first years of schooling. In the paper, a less-known research method based on eye-tracking is presented.

Results: The main results of the research are as follows: According to the findings of the authors, each pupil accepts and understands visual materials individually and this acceptance and understanding of visual materials is influenced by pupils' personality traits. The research also shows that pupils prefer visual materials that depict reality as accurately as possible.

Conclusions: The research was designed as a case study which could be used for further research of a similar form.

Key words: eye tracker, visual materials, children's perception.

Tomáš Svatoš, Faculty of Education, University of Hradec Králové, Hradec Králové, Czech Republic; tomas.svatos@uhk.cz

Martina Maněnová, Faculty of Education, University of Hradec Králové, Hradec Králové, Czech Republic; martina.manenova@uhk.cz 


\section{Acta Technologica Dubnicae \\ volume 7, 2017, issue 1}

\section{Introduction}

Learning processes belong to the group of well-known and well-described topics of pedagogical psychology. Learning processes focus on how information is being received, assorted, incorporated within already existing concepts and restructuralized by people; and how is a piece of information being remembered and then recalled.

In the schooling environment, didactic means are of a great importance for learning. There are two main groups of didactic means: nonmaterial, e.g. educational methods; and material, for the purposes of this article, the authors would like to point out the so called "pedagogic texts" (Gavora, 1992).

In literature, the research of textbooks, course books, spelling books, dictionaries, songbooks, worksheets, etc. comes in two forms: firstly, the main focus of research lies in the text-based information the books provide, and, secondly, in visual materials.

According to Mareš (2013), researchers, teachers and theoreticians centre their attention mainly on the textual parts of the books, because articles and paragraphs form the main components of a textbook and because it is generally considered easier to interpret written texts than pictures.

It is generally agreed upon that both sources of information (textual and visual) should be equally valuable and mutually irreplaceable while learning, because both sources influence a learner in a different way: whilst text represents a "common" means (a language which is a natural means of communication of humans), visual materials represent a specific modality of the "world around us" (as in graphs, diagrams, pictures, maps, etc.) and are not necessarily understood by all learners to the same extent (neither do they necessarily evoke the same ideas and they do not have to influence learning processes in the same way). Nevertheless, it is important that visual information and its effect on education are directly dependent on the form of the information. The form ought to respect developmental and individual differences of "a person in the role of a pupil".

This brief introduction to the topic of learning from visual materials was necessary for formulating the goals of this study. The goals are as follows:

- to present a brief description of the field of learning from visual materials;

- to narrow the field of learning from visual materials to young school children's learning;

- to show new research possibilities of the eye-tracking method, especially during the phase of perceiving the visual materials and expressing their quantitative characteristics; 


\section{Acta Technologica Dubnicae \\ volume 7,2017 , issue 1}

- to perform, analyse and describe the research in the form of a case study among first grade pupils. The goal of this part is to understand the cognitive processes of first-grade pupils while they were learning from visual materials (see part 5.4).

\section{Learning from visual materials}

In this part, the authors provide the reader with the definition of learning from visual materials. Then, the criteria for classification of visual materials are described and explained. Lastly, the function of visual materials is being discussed.

Visual materials, as defined by Mareš (2013, p. 131), are: "materials of mainly nonverbal character used while learning". These materials are often didactically adapted.

Kosslyn (1989) and Mareš (2001) explain the essence of learning from visuals with a diagram shown in Figure 1. Learning from visual materials is a dynamic process that starts with pupils observing a picture and receiving visual information. This information connects with the knowledge and experience already present in pupils' minds. Then, the whole unit, now consisting of both the previously gained experience and the newly acquired piece of knowledge gradually moves from the "simpler type" of memory to the long-term memory.

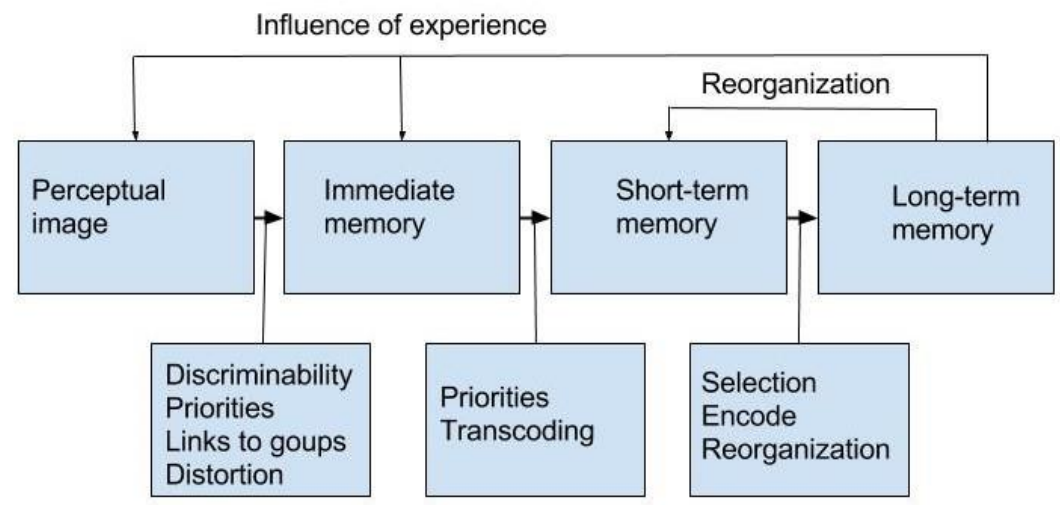

Figure 1. Visual information processing (Kosslyn, 1989; Mareš, 2001).

According to Mareš (1995), the basic classification criterion of visual materials is their pedagogical function. Visual material ought to represent the subject matter, make the text more structured and, therefore, more understandable, "cointerpret" the text and transform the text (e.g. reconstruct the main ideas into a 


\section{Acta Technologica Dubnicae \\ volume 7,2017 , issue 1}

diagram or a chart) to a certain extent and hereby increase its rememberability. Visual materials can be classified based on the extent of abstraction (ranging from concrete such as representation of the real world, to abstract such as diagrams, models, etc.), dimensionality (2D or 3D projection), dynamic character (static or dynamic material), highlighting of selected parts for didactic reasons, interactivity and visually-aesthetic qualities (Mareš, 2013).

Levin, Anglin, and Carney (1987) mention these functions of visual materials: decorative function (visual materials do not necessarily have to correspond with the text), representative function (visual materials reflect information provided by the textual part), organizing function (visual materials support the organization of information and can help with the transition from declarative knowledge to procedural skills), transformative function (visual materials can influence the way pupils process information), affective and motivational function (visual materials can increase pupils' interest in the curriculum), attention improving function and cognitive and regulative function (visual material supports cognitive processes).

Let us briefly debate the last-mentioned feature of visual materials, the dynamics and regulative potential which can be summarized by the term animation and dynamic visualization. Animation and dynamic visualization consist of prearranged and "measured" interpretation of visual information. By doing so, the time dimension is added to learning and perception processes are activated according to an arranged "scenario". Dynamic visualization is very suitable for learning difficult and abstract curriculum content (Rasch \& Snotz, 2009).

Presently, the learning theory works with a new concept of the so called visual keys (Lin \& Atkinson, 2011). Visual keys help with perception and can come in the form of a graphical symbol (an arrow, a zoomed-in detail, etc.) or a static or dynamic (moving) element. All these forms help to differentiate individual parts of an object and understand them. Visual keys sometimes appear in the form of a pedagogical agent, a picture of a person, a head or a talking pictogram.

Lastly, the authors briefly discuss the visual and aesthetic function of visual materials. This function does not affect cognitive operations with visuals directly, it is, however, important for accepting or refusing the curriculum by a learner. Moshagen and Thielsch (2010) observed that a pleasant representation that corresponds with a learner's aesthetic taste is positively reflected in every step of learning and processing visualized curriculum content.

The paper mentions only some pieces of knowledge that describe a wide topic of learning from visuals. Only those are mentioned which the authors found 
important when researching a specific group of learners: children in the role of pupils.

\section{Cognitive and sensual readiness of children for education}

The sense of sight is of the highest importance for pre-school children (or children at the beginning of school attendance) while they familiarize themselves with the outer world. It is known that visual perception directly affects other phenomena, such as speech development, visual and motor coordination, coordination in the three-dimensional world, etc. (Bednáŕová \& Šmardová, 2011).

According to the findings in the field of evolutionary psychology, visual and auditory perception of a child between 5-7 years of age develops to such level that a child can learn the first-grade curriculum. Pre-school children usually focus on objects further in the distance (Papalia \& Olds, 1992), whereas the development of short-distance sight (perception of details) is crucial for schoolwork. Eye lens accommodation often puts strain on learner's attention, which can negatively influence the ability to see small pictures or "small" texts. Children starting school ought to be able to distinguish any kind of shape in any position on any background (firstly, children learn to work with the vertical position and the difference between up and down; then, they learn to work with the horizontal position - right and left side, which is more difficult). For schoolwork, it is important to be able to distinguish two objects visually; small children are not capable of distinguishing letters that vary in position (Matějček, 1987).

Vasta et al. (1995) offer these differences in perception strategies of pres-chool children and young schoolchildren. Pre-school children tackle a problem without any plan and they choose their actions randomly. Young schoolchildren show (to some extent) a systematic nature in their approach: they are able to inspect a picture in a pattern, called systematic exploration or perception strategy. A child ready to enter school is capable of distinguishing between similar pictures, letters, numbers and can differentiate small details, their shape and number. Perception strategy is dependent on maturing and the development of other perception processes (Vágnerová, 2005).

Readiness for attending school shows in the capability of perceiving a whole object (concept) as a system of intertwined details (visual synthesis) and in the capability to break the whole object into parts (visual analysis). Children are capable of perceiving sequences (sequence perception). Sensory-motor 


\section{Acta Technologica Dubnicae \\ volume 7, 2017, issue 1}

coordination affects visual perception, too. Seeing is being coordinated with motor activities (Vágnerová, 2005).

The findings from the field of evolutionary psychology mentioned above are especially important for those that make didactic materials for young schoolchildren. Textbooks ought to contain visual material showing the reality in the extent of abstraction matching the mental skills of the pupils. Generally said, textbooks ought to contain two components (textual and visual) that correspond with each other and aim to help the learner understand the presented content.

The research of children's perception of didactically designed visual materials exceeds the aims of this paper. The works of Czech and Slovak authors Prücha, Gavora, Mareš, Maňák, Klapka and others who pursued this topic can be found in the resources.

While researching perception of visual materials by an individual, technical support and its development are becoming more available and efficient. In the next part of the paper, the subtopic of technical support used while researching the perception of visual materials is discussed.

\section{Technical support used while researching perception of visual materials}

To understand a visual content, it is crucial to fully perceive the picture (see Figure 1). How does such perception work? Are there some "visually more sensitive" places on a picture? Which elements are predominant for perception and which are redundant (out of viewers' interest)? How do we learn from visual materials? Do we stop to focus on some elements more (fixation) or do we get back to the parts of a picture that were unclear to us (saccades)? How much time do we spend on individual parts of a picture, etc.?

To obtain an answer, psychological and pedagogical research uses mainly technical devices. In this paper, the authors will discuss the eye tracker system and its uses in particular. This method is described in detail in Duchowski's summarizing paper (2007).

An eye tracker is a technical device scanning eye movement (eye tracking) and evaluating quantitative characteristics of the movements (Škrabánková \& Trnová, 2014; Škrabánková, 2016). Research participants sit in front of a monitor showing visual information and the device scans their eye movements and attention focus of the participant while observing the presented information. Verbal communication of the participant is also being recorded by the device. 


\section{Acta Technologica Dubnicae \\ volume 7,2017 , issue 1}

The software used for research purposes helps the researchers with computing mainly quantitative data, in this case the data about perception. The software then shows the computed data in a graphical form both to the researcher and the participant. For the purposes of this research, the authors used the Tobii 3.2 program (C) Tobii $\mathrm{AB}$ ). The data are presented in three main forms: mapping (and computation) of fixations and saccades, heat maps (graphical representation of the frequency and the length with which particular areas of a picture were viewed) and cluster representation.

According to Duchowski (2002), today's eye tracking systems are the fourth generation of devices developed for capturing eye movement while watching a picture. However, today's systems are the first that are non-aggressive, interactive and complex (connected to the analyzing software).

Note: Hyökki (2012), Richardson and Spivei (2004) focus on current research that uses eye tracker in their works.

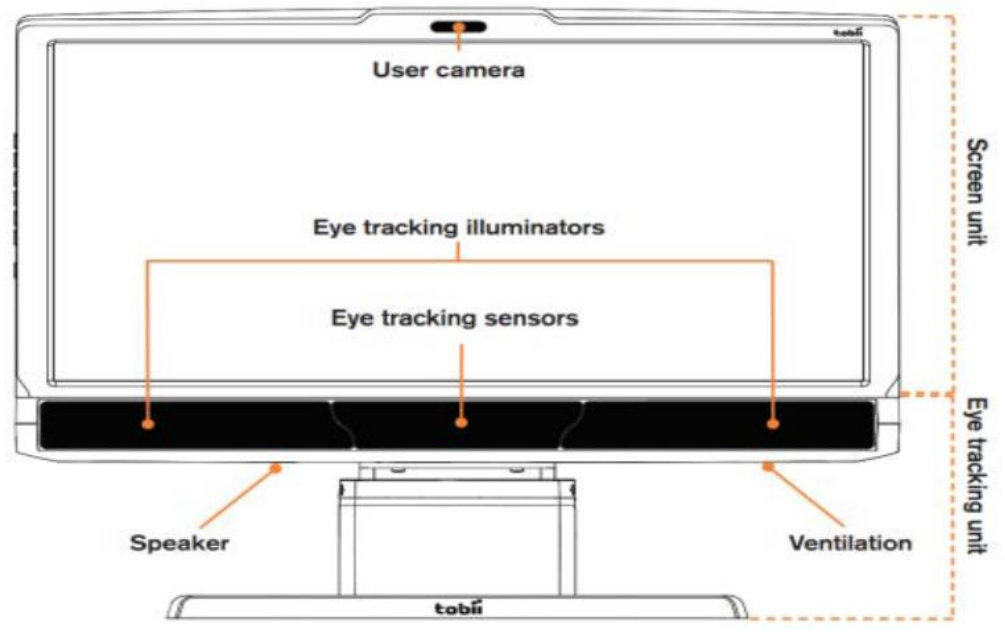

Figure 2. The eye tracking device and set up (Škrabánková \& Trnová, 2014).

The audiovisual record of a discussion between a researcher and a participant was analysed not only by the Tobii system, but also qualitatively (the extent and level of speech was analysed alongside with the participants' dependence on the intermediary, their capability to defend their beliefs and opinions, etc.). This approach is nearing the approach of the so-called video-studies, a method used for example by Janík and Janíková (2006). 


\section{Children's perception of visual materials: a psycho- didactic experiment}

\subsection{Research goals}

The aim of the presented research was to analyse first grade schoolchildren's perception of visual materials. Visual material presented to the schoolchildren consisted of the material included in ordinary textbooks. Specifically, the goals of this research were as follows:

- To observe and analyse the visual trajectories of the participants when one picture was switched for another (from two different textbooks on the same topic).

- To identify why specific pictures were selected by the participants as most correct or most suitable and to record the reasons given.

- To analyse how the participants communicated when a picture was chosen (with respect to the individual and educational qualities of each child).

- To evaluate the experiment and discuss the main results thereof.

\subsection{Methodology used and research phases}

Four randomly chosen first grade pupils were presented with two types of visual materials from two textbooks (both on the topic of spring). Visual material A was formed solely by photographic material, visual material B consisted only of illustrated pictures of spring motifs. Both materials consisted of individual pictures forming a thematic whole. The participants (recorded by the eye tracker and a video camera) watched picture A and then, under the same conditions,

picture B. Then, they were shown both the pictures at the same time and asked which picture is "better", which picture is more accurate according to them. All communication and responses of the participants were recorded and then analysed. A symbolic diagram of research process is depicted in Figure 3. 


\section{Acta Technologica Dubnicae \\ volume 7,2017 , issue 1}

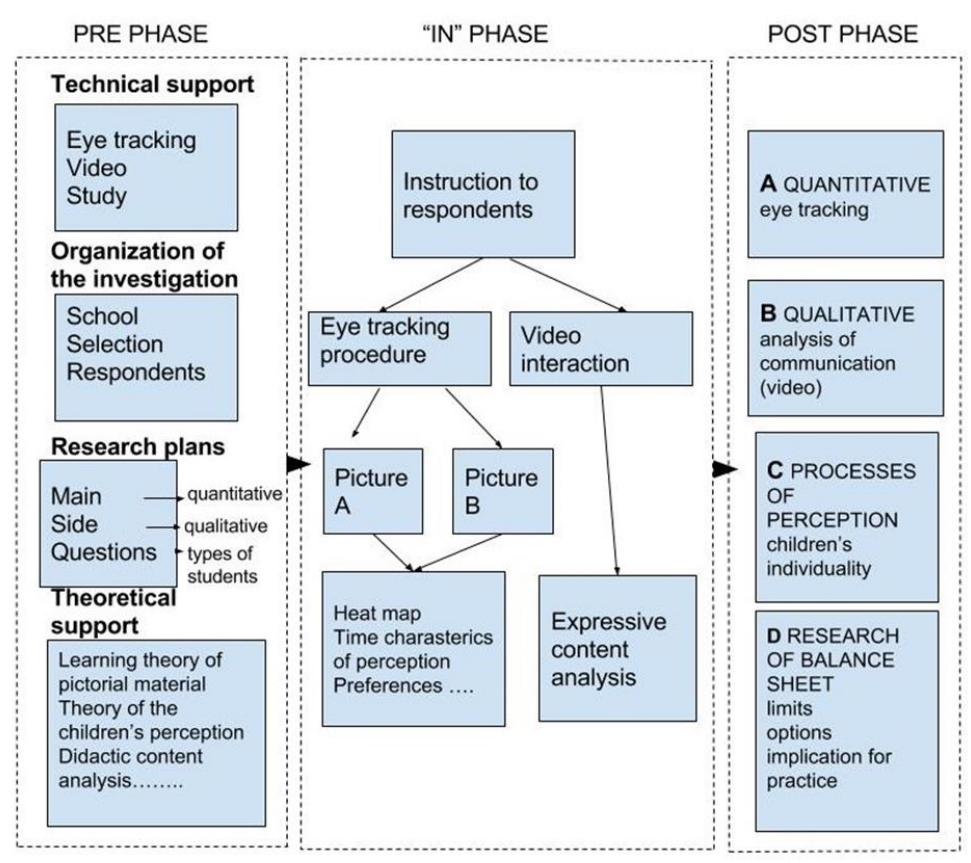

Figure 3. Research phases, their contents and progress.

The research was both qualitative and quantitative in nature. The authors collected research data from observation, discussion, eye tracking (performed by the Tobii system). The length of visual focus on each picture was measured, the trajectory of eye perception was observed and accompanying nonverbal signals (facial expression, gestures, body position, body and limb movement) were marked. When analysing verbal communication, the authors focused on the extent of participants' vocabulary, coherence of their speech, description of remembered pictures and the level of detail included in the description, and on the level of involvement of the intermediary (who was also a member of the research team).

\subsection{Participants}

The research participants in the role of respondents were four first grade pupils of the same public school: two girls and two boys. All of them were chosen at random. A psycho-didactic characteristic of the pupils was given by their class teacher (an experienced teacher who had already spent 7 months teaching the participating pupils).

\section{Karolina}

Karolína is a quiet, kind and forthcoming girl. She is very popular among her peers and has two friends who are boys. During lessons, she is very active and 


\section{Acta Technologica Dubnicae \\ volume 7, 2017, issue 1}

wants to answer questions very often, however, at the same time she does not aggressively compete for attention at the expense of others. She is very bright and solves assignments quickly thanks to her logical thinking. Whenever she makes a mistake (caused in most cases by varying concentration), she tends to be insecure and less confident.

\section{Veronika}

Veronika is a quiet and, compared to her peers, less communicative girl. She is often lost in thought, trying to escape to her inner world. When communicating, she tends to be tactless, even quarrelsome. During lessons, she works a bit slower, but manages to complete assignments correctly in most cases. She does not have any close friends in her class and she likes solving problems on her own. Whenever she makes a mistake, she does not want to accept the misstep and her talk often leads to an argument.

\section{Honza}

Honza is a cheerful, communicative and optimistic boy who is healthily selfconfident. He is very ambitious, is interested in learning and likes to show his knowledge. He gives the impression of a very kind, non-conflict boy. He is capable of admitting his mistakes and learning from them. Honza is very bright and shows deep knowledge about the world around him and about interpersonal relationships.

\section{Šimon}

Šimon is a very introverted boy, but he does not tend to close up and communicates freely with both his peers and the teacher. He is very successful in the subjects that interest him, however, when working on a topic that bores him, he works slowly (both when he works with his hands or mind). During lessons, he is often dependent on teachers' help who motivates him, works on his low self-confidence and supports him to concentrate for longer periods of time.

\subsection{Research results - quantitative data examples and their interpretation}

The participants of the research were shown two pictures: firstly, picture A and then picture B. They were asked to watch the pictures and remember them. Meanwhile, the Tobii system monitored the eye movements of the participants.

The authors were, among other things, interested in the fixation factor (the period of time during which eyes focus on a specific place of a picture in order to remember and understand the information viewed) and about the length of each fixation recorded. In Table 1, the authors present quantitative data obtained. These data show how each pupil reacted to visual materials presented to them and how much time did each pupil need to understand each picture. The 
variation of obtained results is related to sensory-cognitive talents of individual pupils.

Table 1

Fixation length for each picture per participant

\begin{tabular}{lllll}
\hline \multicolumn{1}{c}{$[\mathrm{s}$ ] } & $\begin{array}{c}\text { Pupil D } \\
\text { (Karolina) }\end{array}$ & $\begin{array}{l}\text { Pupil B } \\
(\text { Šimon) }\end{array}$ & $\begin{array}{l}\text { Pupil A } \\
(\text { Honza) }\end{array}$ & $\begin{array}{c}\text { Pupil C } \\
\text { (Veronika) }\end{array}$ \\
$\begin{array}{l}\text { length of first fixation } \\
\text { on picture A }\end{array}$ & 0.18 & 0.49 & 0 & 0 \\
$\begin{array}{l}\text { length of fixation on } \\
\text { picture A }\end{array}$ & 19.91 & 13.64 & 12.77 & 23.09 \\
$\begin{array}{l}\text { length of first fixation } \\
\text { on picture B }\end{array}$ & 0 & 0 & 0 & 0.71 \\
$\begin{array}{l}\text { length of fixation on } \\
\text { picture A }\end{array}$ & 13.30 & 9.10 & 8.45 & 15.10 \\
\hline
\end{tabular}

The heat map method offers an interesting representation of the obtained data. This method marks presented pictures with colours; colours are only applied to places that have been viewed by the participants. Figure 4 shows a heat map of the visual material A. Red spaces marked on the pictures represent places with the longest fixation times. Long fixation time could have been caused by either interest in presented information, or by its visual difficulty.

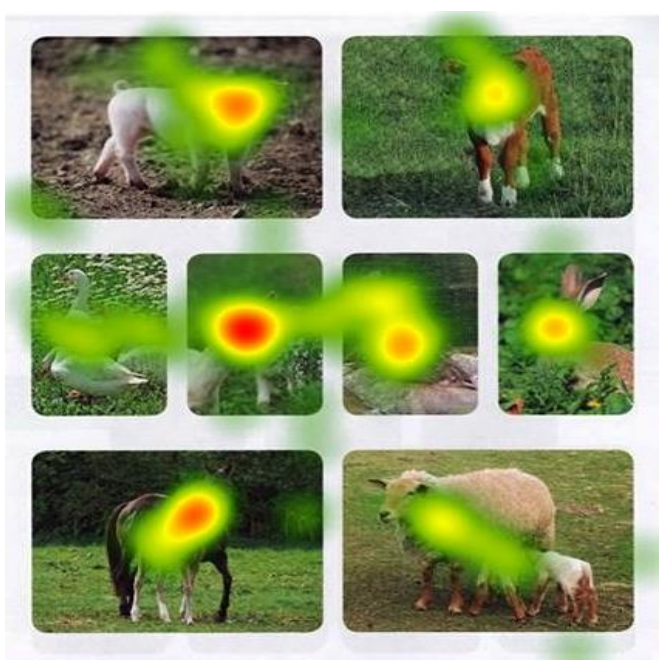

Figure 4. Heat map of the visual material A (data collected from all the participants presented). 

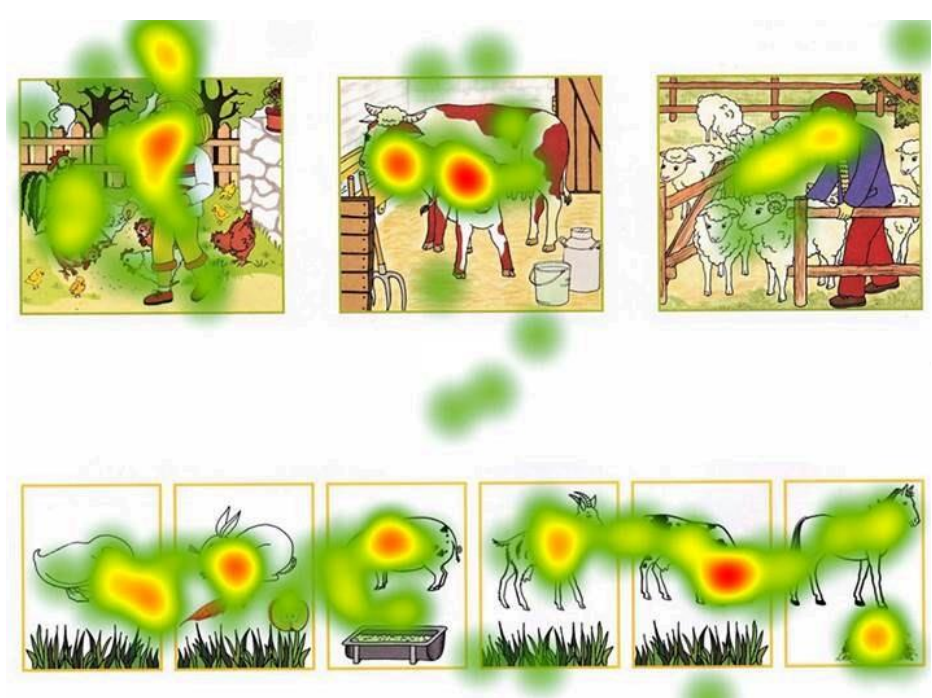

Figure 5. Heat map of the visual material B (collected from all the participants presented).

In the end of this phase, the participants were presented with both sets (A and B) of visual materials. Each participant focused their attention on the visual set A. Just for the record, least visually attractive was the photograph of a duck (middle row, left side). Regarding the focus on details, all pupils were attracted by the heads of the animals shown. The main conclusion of the quantitative part is as follows: research participants paid much more attention to the first set of pictures, visual material A. This set consisted of photographs and the participants found them more accurate and more natural than pictures presented in the visual set $B$.

\subsection{Research results - qualitative data examples and their interpretation Visual material preferred by children}

The analysis of verbal and nonverbal communication of the research participants brought the following results. The authors were interested mainly in the reasons why each participant preferred the visual material A or B. According the data obtained, participants' preference was based on their life experience; children at this age (6-7 in the Czech Republic) are already familiar with animals shown in the pictures. They also know how the depicted animals live, how they usually behave, what is their relationship to humans, what do they eat, etc. That is why the photographs represented spring more accurately than the illustrations. The obtained results show that curriculum presented in the form of a picture (visual material) contains not only cognitive parts, but also emotional ones. This was obvious when the participants talked about the babies of the presented animals: 


\section{Acta Technologica Dubnicae \\ volume 7, 2017, issue 1}

their speech was richer, more adjectives were used (smooth fur, ...) and the children were suddenly happier, as their facial expression showed.

The obtained results can be divided into two groups: mutual and different. Among the group of mutual results, the most important were as follows: every child preferred photographs to illustrations. Every child responded in a very emotional way and every child showed interest in the possibility to arrange individual pictures differently. Results that differed the most from participant to participant were those where inter-individual diversities showed: every child showed a different level of perception, decision making, creativity, communication skills and imagination (in relation to learning).

The second group of results (results that differed the most; results that show how each child tackled the problem presented) is shown in more details in Table 2. The data presented clearly show the correspondence between each child's attributes (as described by the class teacher) and the results obtained during the experiment.

Table 2

Some typical socially-cognitive dimensions (shown for individual participants)

\begin{tabular}{|c|c|c|c|c|}
\hline Dimension & Pupil A & Pupil B & Pupil C & Pupil D \\
\hline Perception & $\begin{array}{l}\text { Fast, } \\
\text { continuous }\end{array}$ & $\begin{array}{l}\text { Restless, slow, } \\
\text { focus on details }\end{array}$ & $\begin{array}{l}\text { Slow, } \\
\text { thorough }\end{array}$ & $\begin{array}{l}\text { Fast, } \\
\text { systematic }\end{array}$ \\
\hline $\begin{array}{l}\text { Decision } \\
\text { making }\end{array}$ & $\begin{array}{l}\text { Independent, } \\
\text { alternative }\end{array}$ & $\begin{array}{l}\text { Non- } \\
\text { internalized, } \\
\text { dependent on the } \\
\text { neighbourhood }\end{array}$ & $\begin{array}{l}\text { "Their own", } \\
\text { difficultly } \\
\text { accounted for }\end{array}$ & $\begin{array}{l}\text { Independent, } \\
\text { accounted for }\end{array}$ \\
\hline Explanation & $\begin{array}{l}\text { Persuasive, } \\
\text { conceptual }\end{array}$ & $\begin{array}{l}\text { Random, non- } \\
\text { systematic }\end{array}$ & $\begin{array}{l}\text { Persuasive, } \\
\text { pragmatic }\end{array}$ & $\begin{array}{l}\text { Persuasive, } \\
\text { intuitive }\end{array}$ \\
\hline $\begin{array}{l}\text { Operation } \\
\text { memory }\end{array}$ & $\begin{array}{l}\text { Significant, } \\
\text { systematic }\end{array}$ & $\begin{array}{l}\text { Small, } \\
\text { undifferentiated }\end{array}$ & $\begin{array}{l}\text { Smaller, } \\
\text { reppoductive }\end{array}$ & $\begin{array}{l}\text { Significant, } \\
\text { structured }\end{array}$ \\
\hline $\begin{array}{c}\text { Verbal } \\
\text { language }\end{array}$ & $\begin{array}{l}\text { Consistent, } \\
\text { factual, rich }\end{array}$ & $\begin{array}{l}\text { Small } \\
\text { production, only } \\
\text { primary } \\
\text { meanings }\end{array}$ & $\begin{array}{l}\text { Smaller } \\
\text { vocabulary, } \\
\text { less fluent }\end{array}$ & $\begin{array}{l}\text { Consistent, } \\
\text { persuasive }\end{array}$ \\
\hline $\begin{array}{c}\text { Personality } \\
\text { type }\end{array}$ & $\begin{array}{l}\text { Balanced, } \\
\text { extroverted }\end{array}$ & $\begin{array}{l}\text { Submissive, } \\
\text { introverted }\end{array}$ & $\begin{array}{l}\text { Balanced, } \\
\text { introverted }\end{array}$ & $\begin{array}{l}\text { Balanced, } \\
\text { extroverted }\end{array}$ \\
\hline
\end{tabular}




\section{Acta Technologica Dubnicae \\ volume 7,2017 , issue 1}

\section{Discussion}

What kind of results did the experiment bring? One of the main parts of the final discussion was that it confirmed the presumption that the way authors of pedagogic texts think (and their visual understanding) differs from that of children: those who use the textbooks to learn. The causes are many (and, besides other things, they show that pupils of the same age who share the same classroom differ individually). Let us mention a single reason for the differences: textbook authors' and teachers' opinions on how to work with textbooks and how to learn from them differ from those of pupils.

The experiment showed that pupils perceive a picture both as a whole and as a set of details. In a picture, there are particular places that the children focused on (some parts were not interesting enough). Children interpret the content of a picture according to their personality and they form emotional links alongside the cognitive ones. Emotional links are often passed by textbook authors.

The experiment has proven that what teachers perceive as a comprehensive, convincing and visually attractive educational content does not have to be perceived as such by the learners. The authors showed that the formation and usage of educational texts (or rather their visual parts) could be different, more helpful for the pupils. A positive change in the approach was recorded when the participants got the chance to change the content and the visual side of presented pictures. Průcha (in Maňák \& Klapko, 2006) reached the same conclusion: Průcha is not satisfied with didactic quality of newly released textbooks, because the quality is not being verified (particularly with respect to pupils' potential).

As a side result, the authors found out that in order to be successful, the psycholinguistic and didactic work of the teachers working with young children needs to be based on the individual knowledge of each pupil ("who is who") in the sense of pupils' cognitive, social and emotional attributes.

In what way could the results of this paper influence schooling? The authors advocate that in school, learning about the real world ought to be based on children's experiences. The life experience of pupils should be included from the very beginning of their education. Children can bring up topics from their social environment and describe them to the others by using their own words and means. This does not mean that no work is done at school; the authors only think that pedagogic texts ought to inspire children to learn and not only provide them with finished pieces of information (Korthagen, 2011). 


\section{Acta Technologica Dubnicae \\ volume 7,2017 , issue 1}

\section{Conclusions}

Results presented in this paper were obtained by using the above-mentioned methods (eye tracking system and discussion record analysis). The authors believe that it is possible to learn how pupils work with visual materials, how do they perceive and remember them even without using complicated and expensive technical devices. Therefore, this paper was not intended as a work in favour of one approach at the expense of another, but as a way to describe how individual pupils perceived visual materials and to offer a path to knowledge the learner could participate in.

\section{References}

Bednářová, J., \& Šmardová, V. (2011). Školní zralost. Brno: Computer Press.

Duchowski, A. T. (2002). A breadth-first survey of eye-tracking applications. Behavior Research Methods, Instruments, \& Computers, 34, 455-470.

Duchowski, A. (2007). Eye tracking methodology: Theory and practice. New York: Springer Science \& Business Media.

Gavora, P. (1992). Žiak a text. Bratislava: SPN.

Hyökki, S. (2012). Eye tracking in user research. Interdisciplinary Studies Journal, 1(4), 65.

Janík, T., \& Janíková, M. (2006) Video studie: Výzkum výuky založený na analýze videozáznamu. Brno: Paido.

Jošt, J. (2006). Oční pohyby a čtení (2nd part). Speciální pedagogika, 16(1), 3649.

Korthagen, F., Kessels, J., Koster, B., Lagerwerf, B., \& Wubbels, T. (2011). Jak spojit teorii s praxi: Didaktika realistického vzděláváni učitelů. Brno: Paido.

Levin, J. R., Anglin, G. J., \& Carney, R. N. (1987). On empirically validating functions of pictures in prose. The psychology of illustration, 1, 51-85.

Lin, L., \& Atkinson, R. (2011). Using animations and visual cueing to support learning of scientific concepts and processes. Computers and Education, 56(3), 650-658.

Maňák, J., \& Klapko, D. (2006). Učebnice pod lupou. Brno: Paido.

Mareš, J. (2001). Učení z obrazového materiálu (pp. 493-503). In J. Č́a \&J. Mareš, Psychologie pro učitele. Praha: Portál.

Mareš, J. (2013). Pedagogická psychologie. Praha: Portál.

Mareš, J., \& Křivohlavý, J. (1995). Komunikace ve škole. Brno: Masarykova univerzita.

Matějček, Z. (2005). Prvnich 6 let ve vývoji a výchově ditěte: normy vývoje a vývojové milniky z pohledu psychologa: základni duševni potřby ditěte: ditè a lidský svět. Praha: Grada Publishing.

Moshagen, M., \& Thielsch, M. T. (2010). Facets of visual aesthetics. International Journal of Human-Computer Studies, 68(10), 689-709. 


\section{Acta Technologica Dubnicae \\ volume 7,2017 , issue 1}

Papalia, D. E., Olds, S. W., \& Feldman, R. (1992). Human Development Edition. New York: McGraw-Hill.

Rasch, T., \& Snotz, W. (2009). Interactive and non-interactive pictures in multimedia learning environments: effects on learning outcomes and learning efficiency. Learning and Instruction, 19(5), 411-422.

Richardson, D. C., \& Spivei, M. J. (2004). Part 1 Eye-Tracking: Characteristics and Methods, Part 2 Eye-Tracking: Research Areas and Applications (pp.1028-1042). In Encyclopedia of Biomaterials and Biomedical Engineering.

Škrabánková, J. (2016). Practical use of the eye camera in pedagogical research (Processing of selected data using the eye tracking method). Acta Technologica Dubnicae, 6(10, 70-77. DOI: 10.1515/atd-2016-0001.

Škrabánková, J., \& Trnová, E. (2014). Researching Students Gifted in Science Using the Method of Eye Tracking. In The 13th APFG Conference on Giftedness. Beijing: China.

Vágnerová, M. (2005). Vývojová psychologie. Praha: Karolinum.

Vasta, R., Haith, M. M., \& Miller, S. A. (1992). Child psychology: The modern science. Hoboken, USA: John Wiley \& Sons. 